\title{
Composite right/left-handed based compact and high gain leaky-wave antenna using complementary spiral resonator on HMSIW for Ku band applications
}

DOI:

10.1049/iet-map.2017.0478

\section{Document Version}

Accepted author manuscript

Link to publication record in Manchester Research Explorer

Citation for published version (APA):

Sarkar, A., Adhikary, M., Sharma, A., Biswas, A., Akhtar, M. J., \& Hu, Z. (2018). Composite right/left-handed based compact and high gain leaky-wave antenna using complementary spiral resonator on HMSIW for Ku band applications. IET Microwaves, Antennas and Propagation, 12(8). https://doi.org/10.1049/iet-map.2017.0478

\section{Published in:}

IET Microwaves, Antennas and Propagation

\section{Citing this paper}

Please note that where the full-text provided on Manchester Research Explorer is the Author Accepted Manuscript or Proof version this may differ from the final Published version. If citing, it is advised that you check and use the publisher's definitive version.

\section{General rights}

Copyright and moral rights for the publications made accessible in the Research Explorer are retained by the authors and/or other copyright owners and it is a condition of accessing publications that users recognise and abide by the legal requirements associated with these rights.

\section{Takedown policy}

If you believe that this document breaches copyright please refer to the University of Manchester's Takedown Procedures [http://man.ac.uk/04Y6Bo] or contact uml.scholarlycommunications@manchester.ac.uk providing relevant details, so we can investigate your claim.

\section{OPEN ACCESS}




\title{
Composite right/left-handed based compact and high gain leaky-wave antenna using complementary spiral resonator on HMSIW for Ku band applications
}

ISSN 1751-8644 doi: 0000000000 www.ietdl.org

\author{
Anirban Sarkar ${ }^{1}$, Moitreya Adhikary ${ }^{1}$, Abhishek Sharma ${ }^{1}$, Animesh Biswas $^{1}$, M. Jaleel Akhtar ${ }^{1}$, Zhirun $^{2}$ \\ $\mathrm{Hu}^{2}$ \\ ${ }^{1}$ Department of Electrical Engineering, Indian Institute of Technology Kanpur, Kanpur, UP-208016, India \\ ${ }^{2}$ School of Electrical and Electronic Engineering, The University of Manchester, Manchester-M139PL, UK \\ $凶$ E-mail: anirban.skr227@gmail.com
}

\begin{abstract}
In this communication, a novel compact high gain composite right/left-handed (CRLH) based leaky-wave antenna (LWA) is presented at Ku band. Half-mode substrate integrated waveguide (HMSIW) incorporating with suitably oriented Complementary Quad Spiral Resonator (CQSR) is used to achieve a CRLH LWA. The uni cell is realized by a CQSR in such a way that orientation of spirals exhibit higher leakage loss having minimum cross coupling between them. The antenna is capable to scan backward to forward along with broadside direction in visible space. The proposed configuration is just length of $4.85 \lambda_{0}$ which can scan within the frequency range of $13.5-17.8 \mathrm{GHz}$ having beam scanning range of $86^{\circ}\left(-66^{\circ}\right.$ to $\left.20^{\circ}\right)$ and maximum gain of $16 \mathrm{dBi}$. The simulated reflection coefficient of the proposed antenna is below $-10 \mathrm{~dB}$ throughout the working frequency range with a side-lobe level of below $-10 \mathrm{~dB}$. The designed prototype is much compact in nature having high gain, fair scanning range, good cross-polarization level along with simpler design methodology and tuning capability to enhance the gain as well as radiation efficiency maintaining fixed size. The proposed antenna could be a promising candidate in Ku-band applications like Fixed Satellite Services (FSS) and Broadcast Satellite Services (BSS) etc.
\end{abstract}

\section{Introduction}

Leaky-wave antennas (LWAs) are affiliated to the travelling-wave antenna family based on transmission line with periodic radiating elements [1]. For the past few decades, numerous LWAs have been reported with the development of various microwave transmission lines (TLs) including rectangular and circular waveguides [2], [3], various planar waveguides like parallel plate waveguides [4], microstrip lines [5], [6], co-planar waveguides [7], dielectric slabs [8] etc.. However, at high frequency it is not feasible to use microstrip based LWAs because of high conductor loss and low efficiency. Though the waveguide based LWAs can be used at higher frequencies but the integration with other planar structure is quite difficult. On the other hand, substrate integrated waveguide (SIW) is a good compromise between dielectric filled waveguide and microstrip and becomes popular in the recent years for its significant advantages such as low profile, low cost, light weight, easy integration [9]. Along with the above advantages, due to their high efficiency, high gain, narrow elevation beamwidth make SIW an attractive candidate for LWA and opens a new avenue for frequency beam scanning application. Several SIW based LWAs have been reported in [10-13]. Over the last few years, the use of half-mode substrate integrated waveguide (HMSIW) in designing leaky-wave antennas has also increased extensively. It avails all the advantageous features of SIW structures along with the size reduction by the factor of half [14], [15]. But these suffer the problem of open stopband (OSB) where broadside radiation is a null. Therefore, backward-broadside-forward frequency beam scanning is not achieved. To mitigate this problem, several techniques are developed and employed in designing LWA with full-space scanning [16-18]. In [19], a quarter-wave transformer, or alternatively a matching stub is proposed to eliminate the stopband in designing 1-D conventional periodic microstrip LWA at K-band but it suffers narrow bandwidth as well as smaller beam scanning range and this concept is validated experimentaly in [20]. Some other techniques are also proposed to

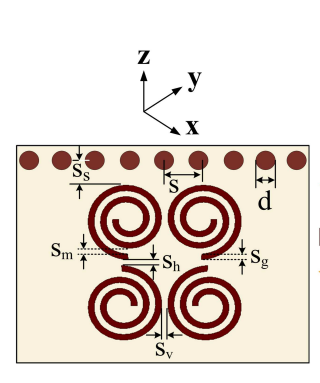

(a)

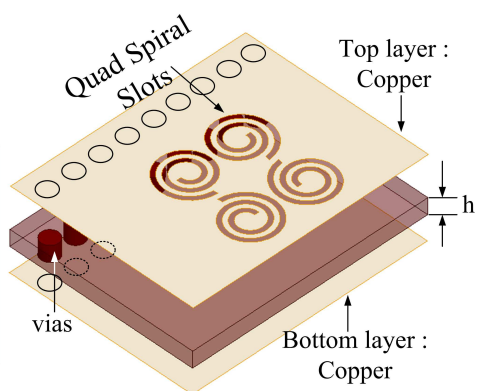

(b)
Fig. 1: (a) Layout of the proposed CQSR unit cell in HMSIW. The parameter values are: $\mathrm{S}=1.6 \mathrm{~mm}, \mathrm{~d}=0.8 \mathrm{~mm}, \mathrm{~S}_{\mathrm{m}}=0.22 \mathrm{~mm}$, $\mathrm{S}_{\mathrm{h}}=0.24 \mathrm{~mm}, \mathrm{~S}_{\mathrm{v}}=0.24 \mathrm{~mm}, \mathrm{~S}_{\mathrm{g}}=0.18 \mathrm{~mm}, \mathrm{~S}_{\mathrm{s}}=1.23 \mathrm{~mm}$. (b) 3-D view of the proposed CQSR unit cell structure.

eliminate the stopband, like unit cells are placed in transversal asymmetry [21], lattice-network based TL model [22], using $\pi$-matching network [23] in designing periodic leaky-wave antennas. In [24], a self-matched periodic LWA is designed in microstrip environment using U-stub and an interdigital capacitor which is compact in size with suitable scanning range but has maximum gain of $10.6 \mathrm{dBi}$. Recently, several CRLH based antennas have been reported using microstrip, SIW, CRLH rectangular waveguide etc. They own some unique features not available for conventional microwave structures such as it supports both backward and forward waves and this is applicable for LWAs for achieving continuous beam steering in visible space. CRLH based LWAs with detailed dispersion analysis in microstrip environment is reported in [25]. A K-Band frequencyscanned LWA based on CRLH TLs is reported in [26]. In [27], the CRLH SIW based LWA with low cross polarization level is 


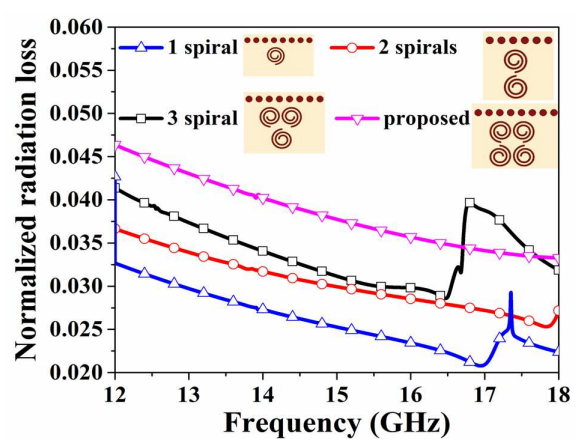

(a)
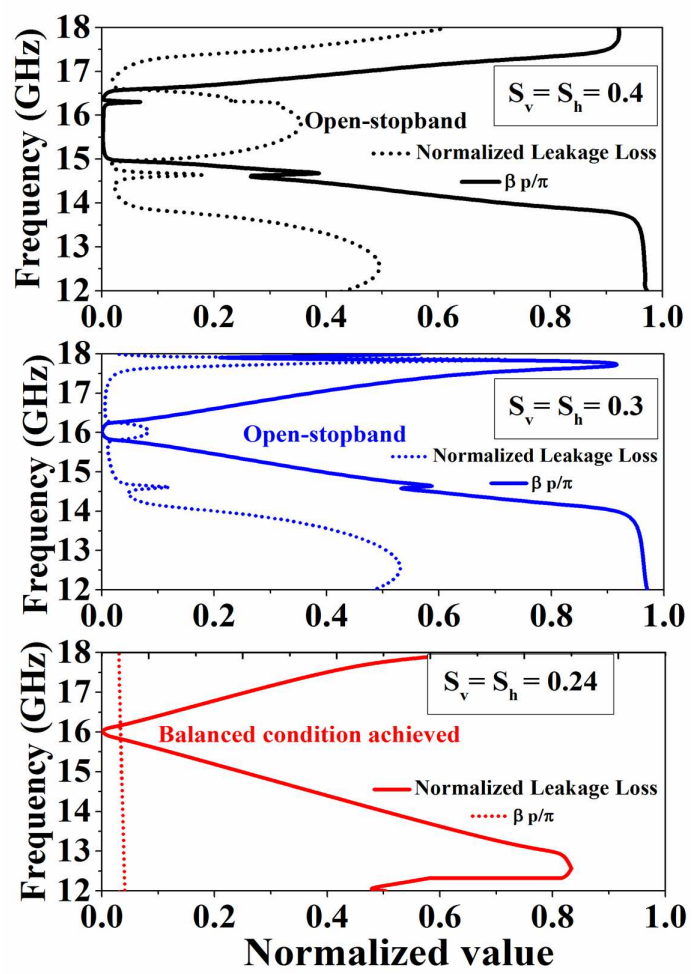

(b)

Fig. 2: Variation of normalized leakage loss for changing (a) the number of spirals, (b) gap between the spirals with openstopband elimination.

shown. The CRLH SIW based LWA with polarization flexibility is shown in [28]. It is to be noted that, the side-wall vias of HMSIW structures provides an effective shunt inductance and hence, to implement the CRLH medium, only series capacitance is required. By utilizing these benifits of HMSIW, several CRLH HMSIW based LWA have been reported in past [14], [29], [30], [31] where full space scanning is achieved by solving the open stopband issues for unbalanced transmission line. However, most of the previously reported antennas are not exhibiting a high gain with significantly decreasing the overall profile of the structure.

Our main aim in this work is to propose a compact low profile leaky-wave antenna having higher gain and improved radiation efficiency which takes advantage of all the characteristics of HMSIW structures. This is facilitated by introducing the novel concept of complementary spiral resonators which help in obtaining better control of design parameters thereby providing easier tuning. The proposed design is also compared with other reported works. To the best of author's knowledge, such type of CRLH based leaky-wave antenna with compact size, high gain, improved side lobe level and more flexible in tuning has not been earlier proposed in literature. The proposed antenna is simulated

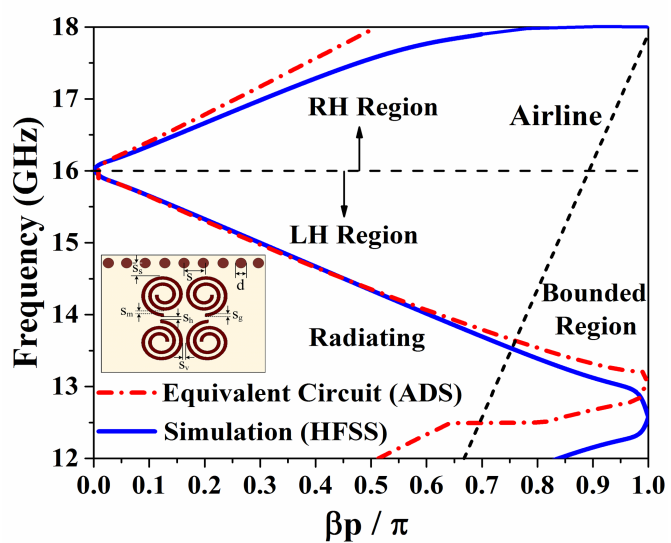

(a)

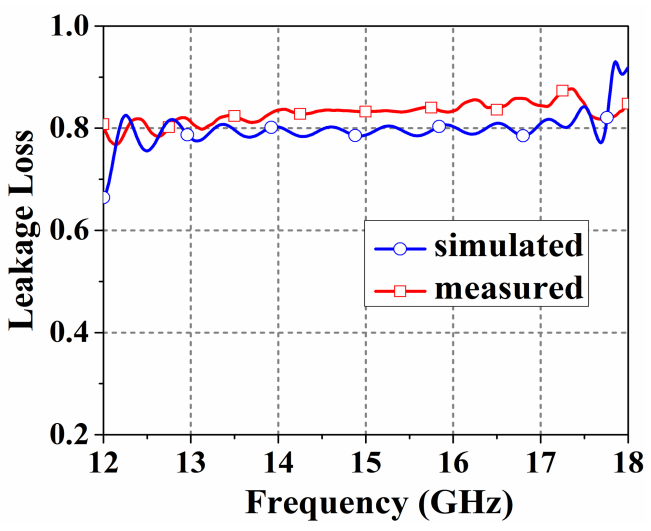

(b)

Fig. 3: (a) Comparison between simulated and optimized dispersion diagram of balanced CQSR unit cell of Fig. 1; (b) simulated and measured leakage loss of the unit cell.

as well as optimized in Ansoft High Frequency Structure Simulator (HFSS) and the same is fabricated and tested. Along with the good frequency scanning range and high gain of the proposed prototype, the antenna is advantageous in terms of compactness, simple single layered fabrication process that can be easily implemented on printed circuit board.

\section{Unit Cell Design and Analysis}

\subsection{Design of Complementary Quad Spiral Resonator (CQSR) Unit Cell}

The top and perspective views of the proposed CQSR unit cell in HMSIW are shown in Fig. 1. The proposed structure is designed on RT/Duroid 5880 substrate with dielectric constant $\left(\epsilon_{r}\right)=2.2$, loss tangent $(\tan \delta)=0.0009$ and height $(\mathrm{h})$ of $0.787 \mathrm{~mm}$. Shunt capacitance and series inductance are distributed along the geometry, which correspond to an equivalent model of ground plane and top wall of the HMSIW structure respectively. A group of four complementary spiral slots are etched on the top wall of the HMSIW which provide series capacitance. Whereas, metallic vias are realized as distributed shunt inductance. Thus, combined effects support the property of left-handed region. The length of the unit cell is chosen by maintaining the homogeneity condition i.e. unit cell length $\ll$ $\lambda_{g} / 4$. By satisfying the balanced condition of the proposed unit cell, backward to forward frequency beam scanning together with broadside radiation is obtained. This implies the elimination of band-gap 


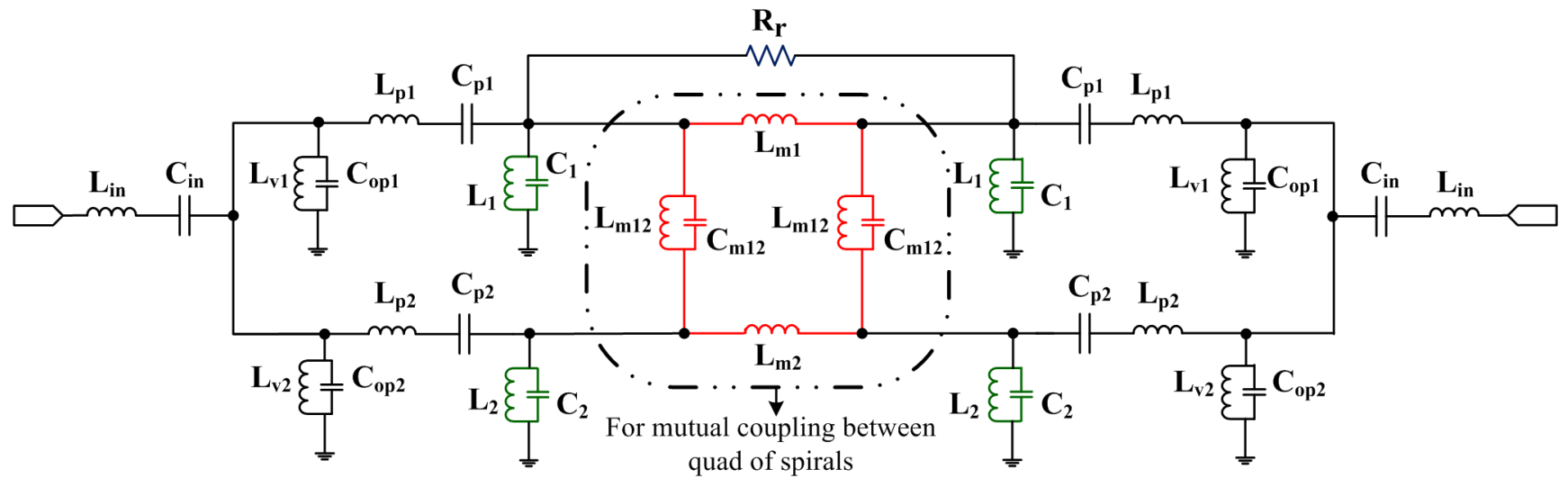

Fig. 4: Equivalent Circuit Model of HMSIW CQSR unit cell. The extracted circuit element values are $\mathrm{L}_{\mathrm{in}}=0.367 \mathrm{nH}, \mathrm{C}_{\mathrm{in}}=0.486 \mathrm{pF}, \mathrm{L}_{\mathrm{v} 1}=2.06$ $\mathrm{nH}, \mathrm{C}_{\mathrm{op} 1}=0.205 \mathrm{pF}, \mathrm{L}_{\mathrm{v} 2}=0.697 \mathrm{nH}, \mathrm{C}_{\mathrm{op} 2}=0.171 \mathrm{pF}, \mathrm{L}_{\mathrm{p} 1}=2.974 \mathrm{nH}, \mathrm{C}_{\mathrm{p} 1}=2.924 \mathrm{pF}, \mathrm{L}_{\mathrm{p} 2}=1.132 \mathrm{nH}, \mathrm{C}_{\mathrm{p} 2}=0.122 \mathrm{pF}, \mathrm{L}_{1}=0.482 \mathrm{nH}, \mathrm{C}_{1}=0.1 \mathrm{pF}$, $\mathrm{L}_{2}=0.887 \mathrm{nH}, \mathrm{C}_{2}=0.942 \mathrm{pF}, \mathrm{L}_{\mathrm{m} 1}=2.99 \mathrm{nH}, \mathrm{L}_{\mathrm{m} 2}=2.97 \mathrm{nH}, \mathrm{L}_{\mathrm{m} 12}=1.905 \mathrm{nH}, \mathrm{C}_{\mathrm{m} 12}=0.452 \mathrm{pF}, \mathrm{R}_{\mathrm{r}}=1.416 \mathrm{ohm}$.

between left-handed and right-handed regions. The balanced condition for the unit cell is established by tuning the values of $\mathrm{S}_{\mathrm{m}}, \mathrm{S}_{\mathrm{h}}$, $S_{\mathrm{v}}, S_{\mathrm{g}}, \mathrm{S}_{\mathrm{s}}$ at a fixed cut-off frequency and the left-handed region only gets affected by these parameters. The quad of spirals with suitable orientation is exploited as a unit cell of the proposed antenna in such a manner that radiation loss in terms of normalized leakage constant is enhanced and showing a smooth variation within desired frequency band. The dependency on number of spirals on selection of unit cell is clearly depicted in Fig. 2(a) from where, it is clear that the proposed configuration with four spirals shows most suitable performance among the depicted four cases (in Fig. 2(a)). Though, similar leakage behavior is achieved from unit cell having two spirals but proposed unit cell is the better selection as side lobe level is also reduced by $\sim 5.41 \mathrm{~dB}$ compared to the unit cell containing two spirals. Moreover, the number of turns of spirals also helps in enhanced leakage loss resulting in improved efficiency and gain. For better understanding, dispersion analysis is done and described next.

\subsection{Dispersion Analysis}

For better realization of the behavior of the leaky-wave antenna, dispersion characteristic of the CQSR unit cell is studied. It is done through driven-mode solution which is more time efficient than eigen-mode simulation. In the full wave simulation of unit cell, wave-port excitation is carried out. By considering the effect of periodicity, the unit cell is simulated in HFSS and the S-parameters are extracted to study the dispersion characteristics. During simulation, the mutual coupling effect between the unit cells is neglected. The dispersion equation for the periodic transmission line can be written as (1) [26]

$$
\cos (\beta p)=\frac{(A+D)}{2}
$$

where $\mathrm{A}$ and $\mathrm{D}$ are the components of a transmission matrix of TL. To extract the dispersion curve from full wave simulation, the equivalent S-parameters of the periodic transmission line can be calculated as (2)

$$
\beta p=\cos ^{-1}\left(\frac{1-S_{11} S_{22}+S_{12} S_{21}}{2 S_{21}}\right)
$$

where $p$ is the periodicity of unit cell, $\beta$ is the propagation constant or radiating space harmonic. In the proposed design, $n=0$ harmonic is responsible for radiation. For traditional transmission line, series inductors and shunt capacitors are the distributed elements which exhibit forward wave propagation. The left-handed transmission line is the dual of right-handed TL structure and it exhibits backwardwave propagation. It is observed from Fig. 3(a), at the transition frequency $(16 \mathrm{GHz})$ of the right and left-handed regions, series $\left(\omega_{s e}\right)$ and shunt $\left(\omega_{s h}\right)$ resonant frequencies are equal. Thus, balance condition is achieved. At this condition, phase constant $\beta$ exhibits zero value at the transition frequency $\left(\omega_{0}\right)$ as mentioned in (3).

$$
\omega_{0}=\frac{1}{\sqrt[4]{L_{R} C_{R} L_{L} C_{L}}}=\omega_{s e}=\omega_{s h}
$$

Below this frequency, the LH region appears which supports the propagation of backward-wave and just above the transition frequency is RH region which supports forward-wave. The simulated and measured leakage loss [34] of unit cell is depicted in Fig. 3(b) where it is clear that the radiation loss has higher value due to the proposed CQSR unit cell. The radiation from the unit cell in terms of leakage loss is varying with low fluctuation from $0.8-0.87$ within the working frequency range which is desired for good antenna design. In Fig. 2(b), the effect of variation in inter-spiral gap $\left(S_{h}\right.$ or $\left.S_{v}\right)$ to determine the balance condition are shown where it varies from $S_{h}=S_{v}=0.4 \mathrm{~mm}$ (with open stop band) to $S_{h}=S_{v}=0.24 \mathrm{~mm}$ (open stop band is eliminated).

\section{Equivalent Circuit Model}

In this proposed LWA, CRLH structure is realized in HMSIW and the equivalent circuit for the proposed structure is modeled by Advanced Designed System software where dispersion characteristic is analyzed through optimization. Primarily, initial values of the equivalent circuit are predicted from S-parameter responses of unbalanced unit-cell (HFSS) by fitting the circuit model in ADS. Further, the equivalent model parameters are tuned in ADS to achieve balance condition. The change in circuit elements values from the initial prediction gives an insight into the direction of required changes in physical parameters of unit cell in HFSS design in order to achieve balanced condition. For example, the change in values of $\mathrm{L}_{\mathrm{m} 12}-\mathrm{C}_{\mathrm{m} 12}$ indicates the corresponding change in physical parameter $S_{h}$. Similarly, change in $L_{m 1}$ and $L_{m 2}$ can be related to corresponding change of $S_{v}$. The width and turns of the complementary spiral can be modeled by the equivalent circuit elements $\mathrm{L}_{1}-\mathrm{C}_{1}$ (for spirals close to the via-wall) and $\mathrm{L}_{2}-\mathrm{C}_{2}$ (for spirals close to the magnetic wall). The detailed and precise equivalent circuit for the proposed HMSIW CQSR unit cell is shown in Fig. 4 where encircled area of the circuit is showing the effect of mutual coupling between the single quad of complementary spirals, neglecting the diagonal mutual coupling. $\mathrm{L}_{1}, \mathrm{C}_{1}, \mathrm{~L}_{2}, \mathrm{C}_{2}$ are coming for quad of spirals which are represented by four L-C tank circuits. The parallel inductors $\left(\mathrm{L}_{\mathrm{v} 1}\right.$ and $\left.\mathrm{L}_{\mathrm{v} 2}\right)$ and capacitors $\left(\mathrm{C}_{\mathrm{op} 1}\right.$ and $\mathrm{C}_{\mathrm{op} 2}$ ) are coming due to the metallic vias and considering the fringing field at the magnetic wall respectively. All the optimized inductors and capacitors values are mentioned in Fig. 4. The comparison between simulated and optimized dispersion characteristic 


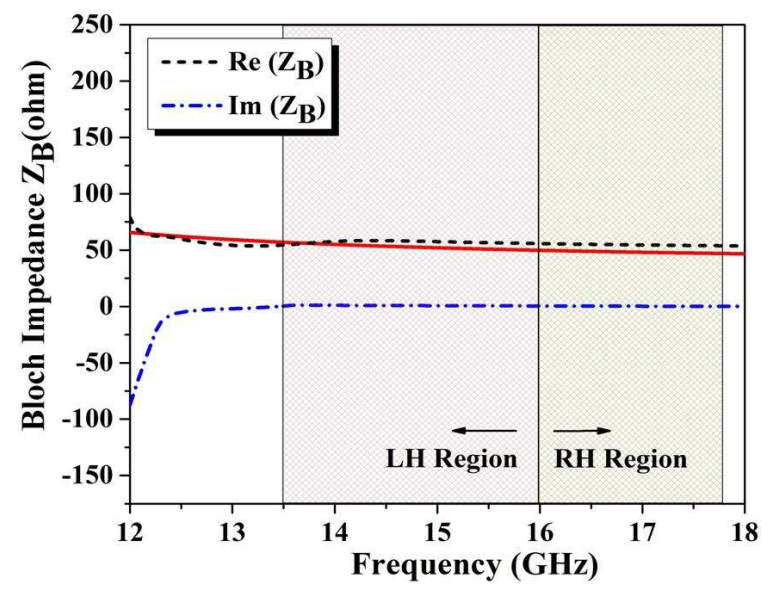

Fig. 5: Real and imaginary part of Bloch impedance $Z_{B} \Omega$ for the proposed structure as a function of frequency. The red line is the impedance at the port of unit cell.

are depicted in Fig. 3(a) and it is showing a good agreement.

$$
Z_{B}=Z_{L} \sqrt{\frac{\left(\frac{\omega}{\omega_{s e}}\right)^{2}-1}{\left(\frac{\omega}{\omega_{s h}}\right)^{2}-1}-\left(\frac{\omega_{L}}{2 \omega}\left[\left(\frac{\omega}{\omega_{s e}}\right)^{2}-1\right]\right)^{2}}
$$

where,

$$
\begin{gathered}
Z_{L}=\sqrt{\frac{L_{L}}{C_{L}}} \quad \omega_{s e}=\frac{1}{\sqrt{L_{R} C_{L}}} \\
\omega_{s h}=\frac{1}{\sqrt{L_{L} C_{R}}} \quad \omega_{L}=\frac{1}{\sqrt{L_{L} C_{L}}} \\
Z_{B}= \pm Z_{0} \sqrt{\frac{\left(1+S_{11}\right)^{2}-S_{21}^{2}}{\left(1-S_{11}\right)^{2}-S_{21}^{2}}}
\end{gathered}
$$

The Bloch wave analysis can be performed through full wave analysis by considering infinitely long structure. Here, Bloch impedance is extracted from $\mathrm{N}$ number of CRLH unit cell i.e. by finite unit cell approach as [32], [33] and is shown in Fig. 5. Mutual coupling is taken into account during analysis. By neglecting the radiation resistance, the Bloch impedance $Z_{B}$ for symmetric CRLH unit cell is expressed as [32], [34] and mentioned in (4)-(6). From Fig. 5 it is clear that the real part of the Bloch impedance is almost matched with the characteristic impedance $Z_{0}$ of the transmission line within the desired frequency range (LH and $\mathrm{RH}$ regions are depicted shaded in figure) of the proposed antenna. In that region, the reactive part of Bloch impedance is almost zero, signifies good matching throughout the working frequency region of the antenna.

\section{$4 \quad$ Leaky-wave Antenna Design}

Periodic LWAs are generally realized by incorporating periodic perturbations to the guided mode of the structure such that $n=0$ becomes radiating harmonic in nature. The unit cell shown in Fig. 1 is placed periodically in series with the periodicity $p$ (maintaining the homogeneity condition i.e. $p \ll \lambda_{g} / 4$ ) in such a manner that the scanning range of the leaky-wave antenna will be in the fast wave region (13.5-17.8 GHz) where $n^{t h}$ space harmonic phase constant $\left(\beta_{n}\right)$ increases from negative $\left(\beta_{n}=-k_{0}\right)$ to positive $\left(\beta_{n}=k_{0}\right)$ values with increment of frequencies. Moreover, the average cell size $p$ must be substantially smaller than the guided wavelength $\lambda_{g}$ to satisfy the homogeneity condition. In the fast wave region, $\beta_{n}$ is less than the free space wave number i.e. $\left|\beta_{n}\right|<k_{0}$ which is necessary radiation condition of LWA. Fig. 6(a) depicts the layout of the

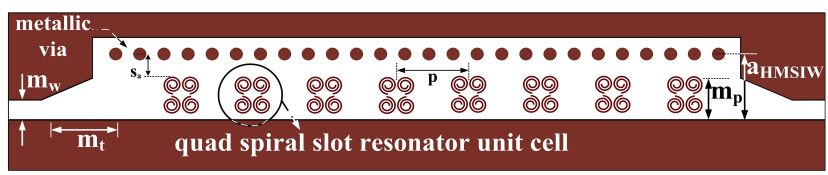

(a)

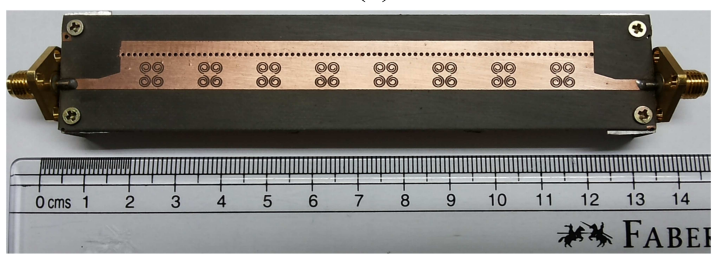

(b)

Fig. 6: Microstrip line fed proposed HMSIW based CRLH CQSR leaky-wave antenna with tapered microstrip transition. The parameter values are: $\mathrm{a}_{\mathrm{HMSIW}}=7.47 \mathrm{~mm}, \mathrm{~m}_{\mathrm{p}}=3.61 \mathrm{~mm}, \mathrm{~m}_{\mathrm{t}}=4.35 \mathrm{~mm}$, $\mathrm{m}_{\mathrm{w}}=2.29 \mathrm{~mm}, \mathrm{~S}_{\mathrm{a}}=1.6 \mathrm{~mm}, \mathrm{p}=12 \mathrm{~mm}$.

$a$ layout of the proposed antenna

$b$ fabricated prototype with 8 unit cells

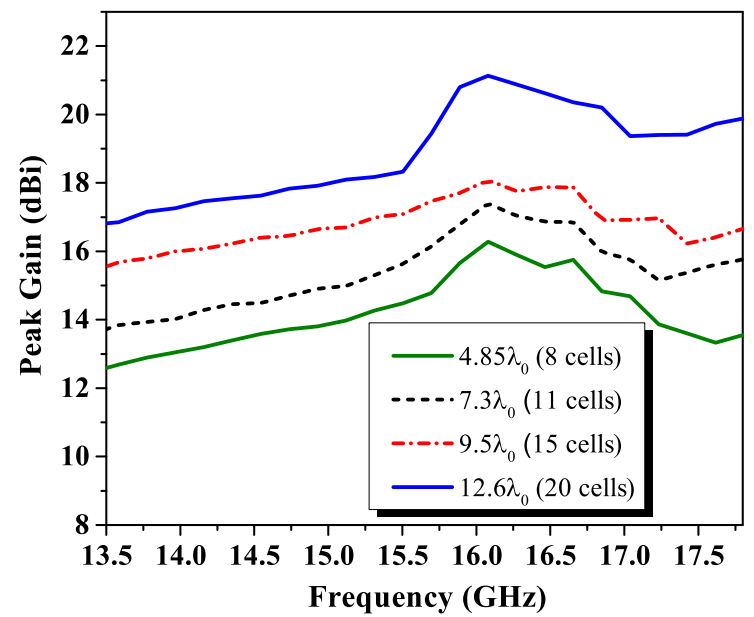

Fig. 7: Variation of simulated gain with frequencies for different lengths.

proposed LWA having eight unit cells. In order to match the structure with the $50 \Omega$ microstrip line, taper-line transitions are used at both ends. The $\mathrm{m}_{\mathrm{t}}$ and $\mathrm{m}_{\mathrm{p}}$ are optimized for the purpose of good matching. The phase constant of the $n^{t h}$ spatial harmonic $\beta_{n}$ determines the direction of radiated main beam measured from broadside direction to both sides of the visible space. The angle of maximum radiated beam direction $\left(\theta_{m}\right)$ can be calculated in dominant mode $n$ $=0$ as $[18]$.

$$
\theta_{m}=\sin ^{-1}\left(\frac{\beta_{n}}{k_{0}}\right)=\sin ^{-1}\left(\frac{\beta_{0}}{k_{0}}+\frac{n \lambda_{0}}{p}\right)
$$

The equation (7) shows that a full space scanning $\left(-90^{\circ}\right.$ to $\left.90^{\circ}\right)$ can be achieved if $\beta_{n}$ varies with the range $\left(-k_{0}, k_{0}\right)$. Fig. 7 shows the variation of simulated peak gain with frequencies for different radiator lengths where gain is increasing with radiator length and is maximum at broadside. The proposed antenna stands as a very good candidate in terms of compactness, frequency scanning range and gain for the applications in this frequency range.

\section{Experimental Verification and Discussion}

The proposed HMSIW CRLH CQSR based leaky-wave antenna are fabricated on Rogers RT/duroid 5880 substrate having the dielectric constant of 2.2, loss tangent $(\tan \delta)$ of 0.0009 and thickness of 


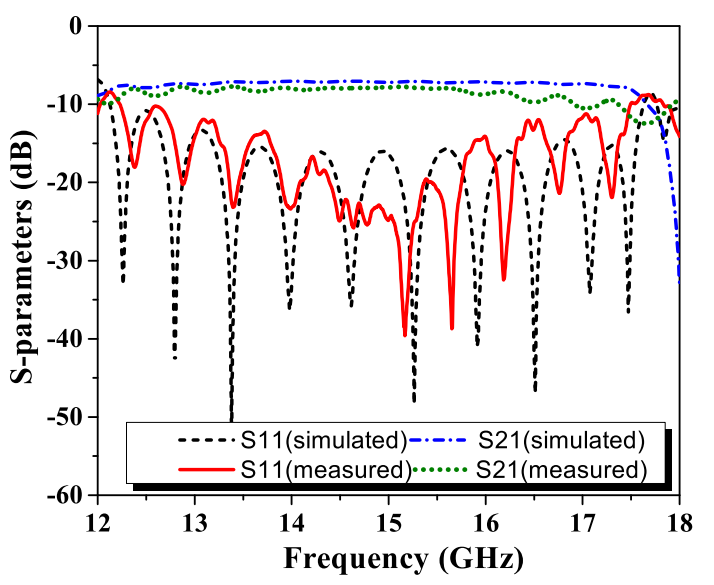

Fig. 8: Comparison of simulated and measured S-parameters with frequency

Table 1 COMPARISON WITH OTHER REPORTED DESIGNS

\begin{tabular}{ccccc}
\hline Ref & $\begin{array}{c}\text { Radiator } \\
\text { Length }\end{array}$ & Bandwidth $(\mathrm{GHz})$ & $\begin{array}{c}\text { Scanning } \\
\text { Range }\end{array}$ & $\begin{array}{c}\text { Peak } \\
\text { Gain }(\mathrm{dBi})\end{array}$ \\
\hline$[19]$ & $22.82 \lambda_{0}$ & $26-27.5(5.6 \%)$ & $10^{\circ}$ & 16 \\
{$[20]$} & $11.57 \lambda_{0}$ & $8-11.4(35.05 \%)$ & $35^{\circ}$ & 21 \\
{$[24]$} & $7.44 \lambda_{0}$ & $5-7(33.33 \%)$ & $155^{\circ}$ & 10.6 \\
{$[26]$} & $12.95 \lambda_{0}$ & $20-30(40 \%)$ & $75^{\circ}$ & 14 \\
{$[27]$} & $5.74 \lambda_{0}$ & $13.5-17.8(27.47 \%)$ & $87^{\circ}$ & 9.4 \\
{$[30]$} & $6.6 \lambda_{0}$ & $8.4-11.4(30.3 \%)$ & $86^{\circ}$ & 11 \\
{$[34]$} & $5.67 \lambda_{0}$ & $8.6-10.3(17.98 \%)$ & $86^{\circ}$ & 11.5 \\
This Work & $\mathbf{4 . 8 5} \lambda_{0}$ & $\mathbf{1 3 . 5 - 1 7 . 8}(\mathbf{2 7 . 4 7 \%})$ & $\mathbf{8 6}^{\circ}$ & $\mathbf{1 6}$ \\
\hline
\end{tabular}

$\lambda_{0}$ : Wavelength at center frequency

$0.787 \mathrm{~mm}$ shown in Fig. 6(b). The overall dimensions of the proposed antenna (including feeding network) are $121.5 \times 24.5 \times 0.787$

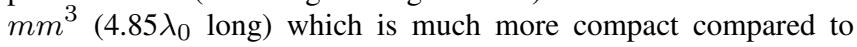
other reported designs with promising property of broadband scanning range at Ku-band. Fig. 8 shows the simulated and measured S-parameters of the proposed antenna which exhibits an impedance bandwidth of $27.47 \%$ (simulated) and $25.80 \%$ (measured) within the radiating fast wave region. The passband before $13.5 \mathrm{GHz}$ signifies the bounded wave propagation and there is a stopband beyond 17.8 GHz. Fig. 9 shows the comparison between simulated and measured normalized $\mathbf{H}$-plane ( $\mathrm{y}-\mathrm{z}$ plane) radiation patterns with frequencies where all of the beam patterns reveals the property of balanced CRLH LWAs, backward to forward continuous frequency beam scanning. In Fig. 8, the radiation patterns at $13.5 \mathrm{GHz}$ to 15 $\mathrm{GHz}$ correspond to the $\mathrm{LH}$ radiation regions, $16 \mathrm{GHz}$ corresponds to broadside radiation and up to $17.8 \mathrm{GHz}$ correspond to $\mathrm{RH}$ radiation regions. By changing the periodicity $p$, the transitional frequency of broadside radiation can be tuned keeping a fair scanning range on both sides from broadside direction. Thus, scanning range can be modified in $\mathrm{RH}$ region due to increase in positive angles. The measured minimum cross-polarization level are achieved as $-20.04 \mathrm{~dB}$ at $13.5 \mathrm{GHz},-26.89 \mathrm{~dB}$ at $14 \mathrm{GHz},-29.26$ dB at $14.5 \mathrm{GHz},-19.82 \mathrm{~dB}$ at $15 \mathrm{GHz},-25.45 \mathrm{~dB}$ at $16 \mathrm{GHz}$ and $-23.05 \mathrm{~dB}$ at $17.8 \mathrm{GHz}$ for the radiated main beam directions of $-66^{\circ},-43^{\circ},-30^{\circ},-17^{\circ}, 0^{\circ}$ and $20^{\circ}$ respectively. The $3-\mathrm{D}$ radiation pattern of the proposed antenna is shown in Fig. 10 where radiated fan beam is scanning with the range of $86^{\circ}$ in visible space (y-z plane) with frequencies. Variation of measured peak gain and simulated radiation efficiency with frequencies of the above mentioned antenna are shown in Fig. 11. Measured antenna gain varies from $12-16 \mathrm{dBi}$ and the estimated radiation efficiency [25] is varied from $82 \%$ to $85 \%$ within the desired frequency range. The proposed antenna is advantageous in terms of compactness and gain with good scanning angle capabilities than other reported designs that concluded in Table 1.
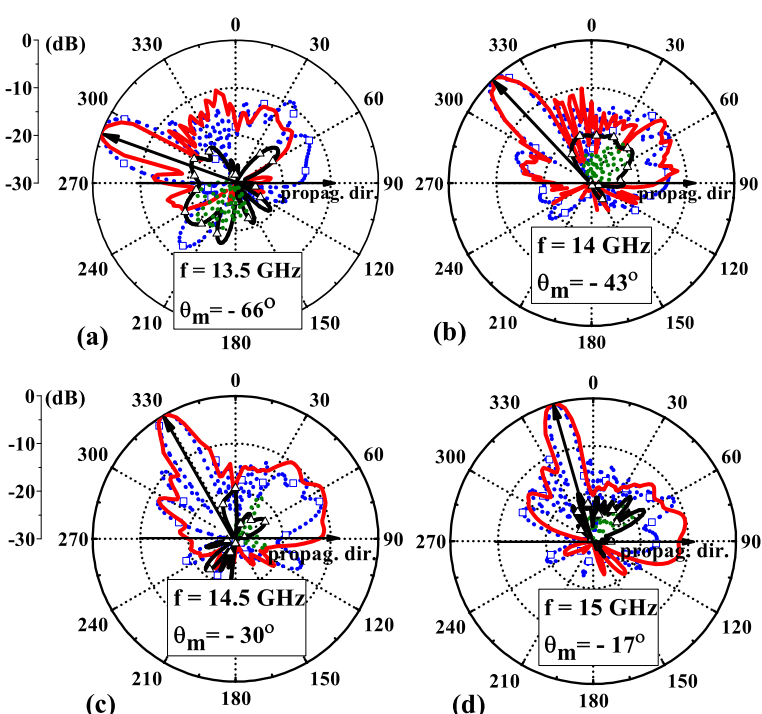

(c)
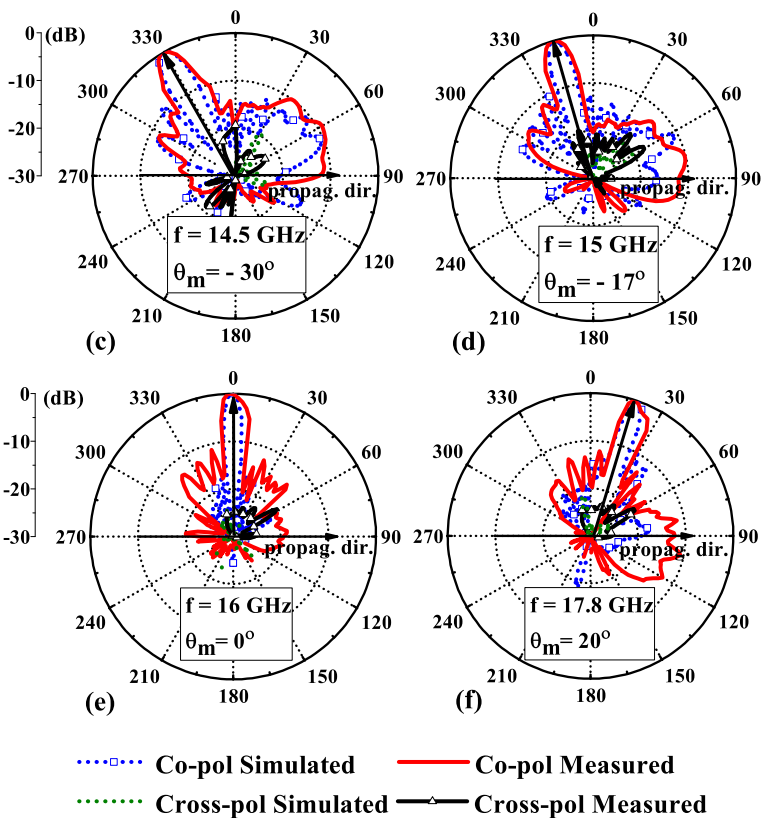

Fig. 9: Comparison of simulated and measured normalized Hplane (y-z plane) radiation patterns at (a) $13.5 \mathrm{GHz}$, (b) $14 \mathrm{GHz}$, (c) $14.5 \mathrm{GHz}$, (d) $15 \mathrm{GHz}$, (e) $16 \mathrm{GHz}$, (f) $17.8 \mathrm{GHz}$.

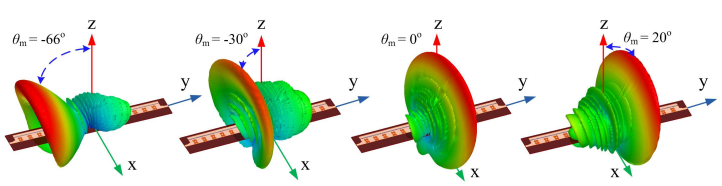

Fig. 10: 3-D fan-beam radiation patterns at $13.5 \mathrm{GHz}, 14.5 \mathrm{GHz}, 16$ $\mathrm{GHz}$ and $17.8 \mathrm{GHz}$ of the antenna.

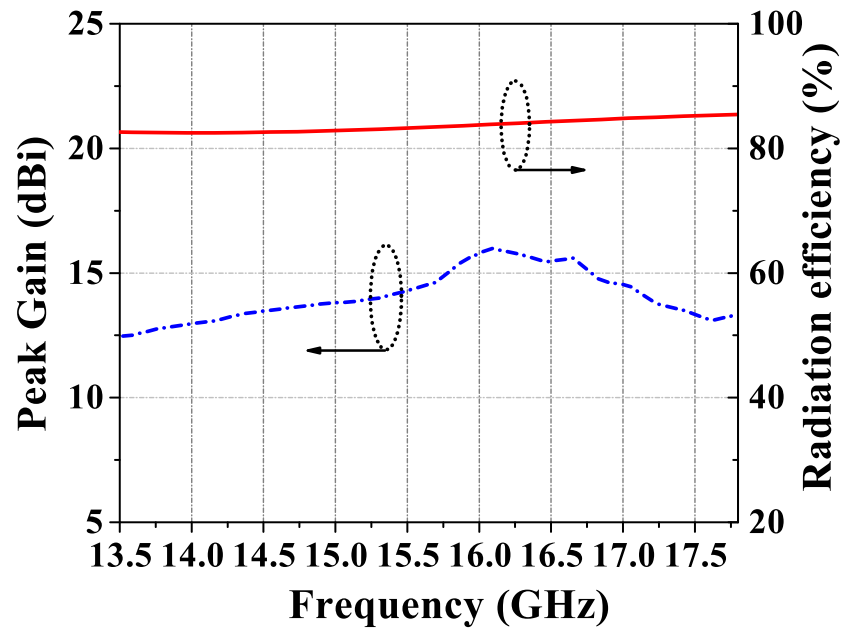

Fig. 11: Variation of measured peak gain and simulated radiation efficiency as a function of frequency for the proposed structure of $4.85 \lambda_{0}$. 


\section{Conclusion}

A compact frequency beam scanning high gain complementary quad spiral resonator based (balanced CRLH) HMSIW LWA is presented at $\mathrm{Ku}$ band. Matched balanced condition is achieved for the unit cell. Thus the proposed geometry is able to scan from backward to forward including broadside direction within a wide frequency range of $13.5-17.8 \mathrm{GHz}$ with a scanning range of $86^{\circ}\left(-66^{\circ}\right.$ to $\left.20^{\circ}\right)$ maximum simulated and measured gain of $16.28 \mathrm{dBi}$ and $16 \mathrm{dBi}$ respectively. The simpler and compact design methodology along with easier tuning capability for further enhancing gain and radiation efficiency make this proposed antenna as an appealing candidate for many practical applications in Ku-band like Fixed Satellite Services (FSS), Broadcast Satellite Services (BSS).

\section{Acknowledgments}

The authors would like to thank Dr. Arun K. Bhattacharyya, Northrop Grumman Systems Corporation for his valuable suggestions.

\section{References}

1 Jackson, D.R., Oliner, A.A.: 'Leaky-wave antennas' in Balanis, C.A., 'Modern Antenna Handbook' (Ed. Hoboken, NJ, USA: Wiley, blue)

2 Goldstone, L.O., Oliner, A.A.: 'Leaky-wave antennas I: rectangular waveguides', IEEE Trans. Antennas Propag., 1959, 7, (10), pp. 307-319

3 Goldstone, L.O., Oliner, A.A.: 'Leaky-wave antennas ii: circular waveguides', IEEE Trans. Antennas Propag., 1961, 9, (3), pp. 280-290

4 Lee, U.H.C.J.I., Cho, Y.K.: 'Analysis for a dielectric filled parallel plate waveguide with finite number of periodic slots in its upper wall as a leaky-wave antenna', IEEE Trans. Antennas Propag., 1999, 47, (4), pp. 701-706

5 Menzel, W.: 'A new traveling wave antenna in microstrip', in Proc. 8th IEEE European Microwave Conf. 1978, pp. 302-306

6 Liu, J., Long, Y.: 'Analysis of a microstrip leaky-wave antenna loaded with shorted stubs', IEEE Antennas Wireless Propag. Lett., 2008, 7, pp. 501-504

7 Grbic, A., Eleftheriades, G.V.: 'Leaky CPW-based slot antenna arrays for millimeter wave applications', IEEE Trans. Antennas Propag., 2002, 50, (11), pp. 1494-1504

8 Schwering, F.K., Peng, S.T.: 'Design of dielectric grating antennas for millimeter wave applications', IEEE Trans. Microw. Theory Tech., 1983, 31, (2), pp. 199-209 9 Deslandes, D., Wu, K.: 'Single-substrate integration technique of planar circuits and waveguide filters', IEEE Trans. Antennas Propag., 51, (2), pp. 593-596

10 Deslandes, D., Wu, K.: 'Substrate integrated waveguide leaky-wave antenna: Concept and design considerations', in IEEE Asia-Pacific Microwave Conf, 2005, Suzhou, China

11 Liu, J., Tang, X., Li, Y., Long, Y.: 'Substrate integrated waveguide leaky-wave antenna with H-shaped slots', IEEE Trans. Antennas Propag., 2012, 60, (8), pp. 3962-3967

12 Liu, J., Jackson, D., Long, Y.: 'Substrate integrated waveguide (SIW) leaky-wave antenna with transverse slots, âĂİ IEEE Trans. Antennas Propag., 2012, 60, (1), pp. 20-29

13 Mohtashami, Y., Rashed-Mohassel, J.: 'A butterfly substrate integrated waveguide leaky-wave antenna', IEEE Trans. Antennas Propag., 2014, 62, (6), pp. 3384-3388

14 Xu, J., Hong, W., Tang, H., Kuai, Z., Wu, K.: 'Half-mode substrate integrated waveguide (hmsiw) leaky-wave antenna for millimeterwave applications', IEEE Antennas Wireless Propag. Lett., 2008, 7, pp. 85-88

15 Saghati, A.P., Mirsalehi, M.M., Neshati, M.H.: 'A HMSIW circularly polarized leaky-wave antenna with backward, broadside, and forward radiation', IEEE Antennas Wireless Propag. Lett., 2014, 13, pp. 451-454

16 Caloz, C., Itoh, T.: 'Electromagnetic Metamaterials: Transmission Line Theory and Microwave Applications' (Hoboken, NJ: Wiley/IEEE, 2005)

17 Liu, L., Caloz, C., and Itoh, T.: 'Dominant mode leaky-wave antenna with backfireto-endfire scanning capability', Electronics Lett., 2002, 38, (23), pp. 1414-1416

18 Caloz, C., Jackson, D.R., Itoh, T.: 'Leaky-wave antennas', in Gross, F.B. (Ed.):'Frontiers in Antennas' ch 9, (New York, NY, USA: McGrawHill, 2011)

19 Paulotto, S., Baccarelli, P., Frezza, F., Jackson, D.R.: 'A novel technique for openstopband suppression in 1-D periodic printed leakywave antennas', IEEE Trans. Antennas Propag., 2009, 57, (7), pp. 1894-1906

20 Williams J. T., Baccarelli P., Paulotto S., and Jackson D. R., 1-D combline leakywave antenna with the open-stopband suppressed: Design considerations and comparisons with measurements, IEEE Trans. Antennas Propag., 2013, 61 (9), pp. $4484-4492$.

21 Otto S., Al-Bassam A., Rennings A., Solbach K., and Caloz C., 'Transversal asymmetry in periodic leaky-wave antennas for bloch impedance and radiation efficiency equalization through broadside', IEEE Trans. Antennas Propag., 2014, 62, (10), pp. 5037-5054.

22 Otto S., Rennings A., Solbach K., and Caloz C., 'Transmission line modeling and asymptotic formulas for periodic leaky-wave antennas scanning through broadside,' IEEE Trans. Antennas Propag., 2011, 59, (10), pp. 3695-3709.

23 Baccarelli P., Paulotto S., and Jackson D. R., 'A pi matching network to eliminate the open-stopband in 1-d periodic leaky-wave antennas,' in Proceedings of the 2012 IEEE International Symposium on Antennas and Propagation, July. 2012 Chicago, IL, pp. 1-2.

24 Paulotto S., Baccarelli P., and Jackson D. R., 'A self-matched wide scanning U-stub microstrip periodic leaky-wave antenna,' J Electromagnet Wave, 2014, 28, (2), pp. 151-164.

25 Paulotto S., Baccarelli P., Frezza F., and Jackson D. R., 'Full-wave modal dispersion analysis and broadside optimization for a class of microstrip CRLH leaky-wave antennas,' IEEE Trans. Microw. Theory Tech., 2008, 56, (12), pp. 2826-2837.

26 Jiang W., Liu C., Zhang B., and Menzel W., 'K-band frequency-scanned leakywave antenna based on composite right/left-handed transmission lines,' IEEE Antennas Wireless Propag. Lett., 2013, 12, pp. 1133-1136.

27 Zhang H., Jiao Y. C., Zhao G., and Zhang C., 'CRLH-SIW-based leaky wave antenna with low cross-polarisation for Ku-band applications,' Electronics Lett., 2016, 52, (17), pp. 1426-1428.

28 Dong Y. and Itoh T., 'Substrate integrated composite right-/left-handed leaky-wave structure for polarization-flexible antenna application,' IEEE Trans. Antennas Propag., 2012, 60, (2), pp. 760-771.

29 Dong Y. and Itoh T., 'Composite right/left-handed substrate integrated waveguide and half mode substrate integrated waveguide leaky-wave structures,' IEEE Trans. Antennas Propag., 2011, 59, (3), pp. 767-775.

30 Henry R. and Okoniewski M., 'A broadside-scanning half-mode substrate integrated waveguide periodic leaky-wave antenna,' IEEE Antennas Wireless Propag. Lett., 2014, 13, pp. 1429-1432

31 Oliner A. and Jackson D. R., Antenna Engineering Handbook. New York, NY, USA: McGraw-Hill, 1993, ch. 11.

32 Collin R., Foundations for Microwave Engineering. 2nd ed. New York, NY, USA McGraw-Hill, 1992, ch. 8.

33 Suntives, A. and Hum, S. V., 'An electronically tunable half-mode substrate integrated waveguide leaky-wave antenna,' in Proceedings of the 5th European Conference on Antennas and Propagation (EUCAP), April 2011, pp. 3670-3674.

34 Yang Q., Zhao X., and Zhang Y., 'Composite right/left-handed ridge substrate integrated waveguide slot array antennas,' IEEE Trans. Antennas Propag., 2014, 62, (4), pp. 2311-2316. 